\title{
Analysis of the Quality of Hospital Waste in Bengkulu City
}

\author{
Evelyne Riandini ${ }^{1, *}$ Dhiatama Tauhida Nisa ${ }^{2}$ Della Septa Sari ${ }^{3}$ \\ ${ }^{1}$ Department of Biology, Faculty of Mathematics and Natural Sciences, Universitas of Bengkulu, Kandang \\ Limun, Bengkulu 38371, Indonesia. \\ ${ }^{2}$ Undergraduate Student, Department of Biology, Faculty of Mathematics and Natural Sciences, Universitas of \\ Bengkulu, Kandang Limun, Bengkulu 38371, Indonesia \\ ${ }^{3}$ UPTD Environmental Laboratory, Environmental Service of Bengkulu City, Jalur Tugu Hiu, Bengkulu, 38119 , \\ Indonesia \\ *Corresponding author. Email: eriandini@unib.ac.id
}

\begin{abstract}
Hospital wastewater can contain pathogenic microorganisms and harmful chemicals that could affect the environment and the organism around. Testing the quality of wastewater is necessary to determine the level of pathogenic microorganisms or organic and inorganic compounds by testing with physics, chemistry, and biologcal parameters. These tests are performed to identify the quality of wastewater and the factors that influence it, as well as to know the techniques and parameters used in the quality analysis of wastewater. The quality analysis of wastewater using three test of parameters, which include temperature test and TSS (Total Suspended Solid) wich contitudes the physics parameter $(14 \mathrm{mg} / \mathrm{L})$, an inorganic chemical parameter that consist the test of $\mathrm{Ph}(7.51)$, iron $(\mathrm{Fe})(0.018 \mathrm{mg} / \mathrm{L})$, manganese $(\mathrm{Mn})(0.013 \mathrm{mg} / \mathrm{L})$, copper $(\mathrm{Cu})(2 \mathrm{mg} / \mathrm{L})$, nitrite $\left(\mathrm{NO}_{2}\right)$ $(0.008 \mathrm{mg} / \mathrm{L})$, sulfide $\left(\mathrm{S}^{2-}\right)(0.005 \mathrm{mg} / \mathrm{L})$, BOD (Biochemical Oxygen Demand) $(25 \mathrm{mg} / \mathrm{L})$, COD (Chemical Oxygen Demand) (55 mg/L), oils and fats, MBAS (Methylene Blue Active Surfactant) (0.306 mg/L), ammonia $\left(\mathrm{NH}_{3}-\mathrm{N}\right)(0.860 \mathrm{mg} / \mathrm{L})$, and the microbiology parameter which is total coliform test $(2940 \mathrm{MPN} / 100 \mathrm{ml})$. These tests are performed according to Indonesian national standards (SNI) and work instructions of environmental laboratory (IK LL). Result from the test showed that quality value of the wastewater analysis does not exceed the quality standards from PERMEN LH NO 5 TH 2014 and PERMEN LH RI No. P.68/Menlhk-Setjen/2016. Based on the result showed that the intalation of wastewater treatment work properly according to the quality standard from the government.
\end{abstract}

Keywords: Analysis, quality sewage, hospital, Bengkulu City

\section{INTRODUCTION}

Wastewater from hospital activities should be treated first before being distributed to the environment, it is because the wastewater can cause the risk of water pollution and trigger disease transmission [1]. The infection and environmental pollution caused by the content of organic, inorganic, pathogenic microorganism, and dangerous chemical compound in wastewater [2].

Based on the government regulations in Peraturan Menteri Lingkungan Hidup dan Kehutanan Republik Indonesia Nomor
P.68/MENLHK-SETJEN/2016 set the quality standard for wastewater and obligate the procedure of Wastewater Treatment Plant (WWTP).

There are several ways in Wastewater Treatment Plant (WWTP) to escalate the quality standard of wastewater, icludes: primary treatment comprise sedimentation, secondary treatment comprises aerobic and anaerobic treatment using Completely Mixed Activated Sludge (CMAS), tertiary treatment comprises trickling filter and chlorination [1]. Based the research by [3], we noticed even though the hospital already facilitated with WWTP, there is still possibility for wastewater unqualified the standard 
from government that be affected by efficiency of WWTP only work for $50 \%$.

This research intent to know the quality standard of hospital wastewater from WWTP outlet using comparison between the value from analysis with the quality standard from government. There is several factors to know the quality standard of wastewater form hospital activities, includes: physical factor comprises temperature test and TSS (Total Suspended Solid), inorganic chemical factor consist the test of $\mathrm{pH}$, iron $(\mathrm{Fe})$, manganese $(\mathrm{Mn})$, copper $(\mathrm{Cu})$, nitrite $\left(\mathrm{NO}_{2}\right)$, sulfide $\left(\mathrm{S}^{2-}\right)$, BOD (Biochemical Oxygen Demand), COD (Chemical Oxygen Demand), oils and fats, MBAS (Methylene Blue Active Surfactant), ammonia $\left(\mathrm{NH}_{3}-\mathrm{N}\right)$, and the microbiology factor which is total coliform test.

\section{MATERIALS AND METHODS}

This research constitutes the quantitative research which is carried out in Regional Technical Implementation Unit (UPTD) Environmental Health Services in Bengkulu City from August $14^{\text {th }}$ until September $12^{\text {th }} 2020$. For 2 litres sample used from wastewater in WWTP outlet hospital, that properly delivered to Regional Technical Implementation Unit (UPTD) Environmental Laboratory.

The sample tested with 3 analysis factors (physical, inorganic chemical, and microbiology) using the parameters test based on Indonesian Natonal Standard (SNI) from National Standardization Agency of Indonesia (BSN). The test results from analysis be compared to quality standard from Peraturan Menteri Lingkungan Hidup RI Nomor 5 tahun 2014 and Peraturan Menteri Lingkungan Hidup dan Kehutanan RI Nomor P.68/Menlhk-Setjen/2016.

\section{RESULT AND DISCUSSION}

The hospital wastewater including all of waste product from hospital activity, content domestics wastewater, wastewater from clinical unite, and laboratory examination. Wastewater from hospital provoke pollution in environment if the materials content disproportionate to the quality standard from government.

Before being distributed to the environment, hospital wastewater needs to go through a treatment process so that it is not harmful to the environment and surrounding organisms, therefore the quality standard of wastewater needs to be considered so that it does not exceed the predetermined limits.

\subsection{Physical Parameters}

\subsubsection{Temperature}

Temperature test was carried out using the SNI 06-6989.23-2005 method using water thermometer type HI 93510. The results of this test have a value of $27^{\circ} \mathrm{C}$, while the quality standard of wastewater for hospital activities based on Peraturan Menteri Lingkungan Hidup RI Nomor 5 tahun 2014 is not more than $38^{\circ} \mathrm{C}$, so the temperature value of hospital waste is declared to meet the standard because it does not pass the quality standard.

Table 1. The measurements analysis result from wastewater test according to parameters

\begin{tabular}{|c|c|c|c|c|c|}
\hline No & Parameters & Unit & $\begin{array}{c}\text { Analysis } \\
\text { Results }\end{array}$ & $\begin{array}{c}\text { Quality } \\
\text { Standard }\end{array}$ & Analysis Methods \\
\hline \multicolumn{6}{|c|}{ Physics } \\
\hline 1. & Temperature & ${ }^{\circ} \mathrm{C}$ & 27 & 38 & SNI 06-6989. 23-2005 \\
\hline 2. & TSS & $\mathrm{mg} / \mathrm{L}$ & 14 & 30 & SNI 06-6989.3-2004 \\
\hline \multicolumn{6}{|c|}{ Inorganic Chemical } \\
\hline 1. & $\mathrm{pH}$ & - & 7.51 & $6.5-9.0$ & SNI 6989.11-2004 \\
\hline 2. & Iron $(\mathrm{Fe})$ & $\mathrm{mg} / \mathrm{L}$ & 0.018 & 5 & IK NO.15.34/IK/LL/2018 \\
\hline 3. & Manganese (Mn) & $\mathrm{mg} / \mathrm{L}$ & 0.013 & 2 & IK NO.15.32/IK/LL/2018 \\
\hline 4. & Copper $(\mathrm{Cu})$ & $\mathrm{mg} / \mathrm{L}$ & 0.020 & 2 & IK NO.15.27/IK/LL/2018 \\
\hline 5. & Nitrite $\left(\mathrm{NO}_{2}^{-}\right)$ & $\mathrm{mg} / \mathrm{L}$ & 0.008 & 1 & IK NO.15.28/IK/LL/2018 \\
\hline 6. & Sulfide $\left(S^{2-}\right)$ & $\mathrm{mg} / \mathrm{L}$ & 0.005 & 0.05 & IK NO.15.31/IK/LL/2018 \\
\hline 7. & BOD & $\mathrm{mg} / \mathrm{L}$ & 25 & 30 & SNI 6989.72-2009 \\
\hline 8. & COD & $\mathrm{mg} / \mathrm{L}$ & 55 & 100 & SNI 6989.2-2009 \\
\hline 9. & Oils and Fats & $\mathrm{mg} / \mathrm{L}$ & 0.017 & 5 & SNI 6989.10-2011 \\
\hline 10. & MBAS & $\mathrm{mg} / \mathrm{L}$ & 0.306 & 10 & IK NO.15.36/IK/LL/2018 \\
\hline 11. & Amomonia $\left(\mathrm{NH}_{3}-\mathrm{N}\right)$ & $\mathrm{mg} / \mathrm{L}$ & 0.860 & 1 & SNI 6989.30-2005 \\
\hline \multicolumn{6}{|c|}{ Microbiology } \\
\hline 1. & Total Coliform & MPN/100 ml & 2940 & 3000 & MPN \\
\hline
\end{tabular}




\subsubsection{TSS (Total Suspended Solid)}

At this parameter, the method that used is gravimetrical from SNI 06-6989.3-2004, where the TSS quality based on Peraturan Menteri Lingkungan Hidup RI Nomor 5 tahun 2014 has a maximum value of $30 \mathrm{mg} / \mathrm{L}$. Therefore, the sample meets the standard because it has a value of $14 \mathrm{mg} / \mathrm{L}$. The value of this TSS should be noted because the rate of suspension residue on a sample can affect damage in water, where the turbidity of the wastewater can affect the light that enters and interfere the photosynthetic orgnasim. That would disturb the ecosystem balance or decrease oxygen levels in water.

TSS test used filter paper that will eventually hold material content in sample, drying with an oven helps to eliminate any remaining water on the paper, so the final weight is only from the suspension weight and filter paper. Measurable final weight value is added into this formula:

$$
\begin{aligned}
(\text { TSS }) & =\frac{\text { Final weight }(g)-\text { Initial weight }(g)}{\text { Sample volume }(\mathrm{ml})} \times 10^{6} \\
& =\frac{0,0962-0,0920}{300} \times 1.000 .000 \\
& =\frac{4200}{300} \\
& =14 \mathrm{mg} / \mathrm{l}
\end{aligned}
$$

\subsection{Inorganic Chemical Parameters}

\subsection{1. $p H$}

The $\mathrm{pH}$ measurement follows the method from Indonesian National Standard SNI 6989.11-2004. The measurement results from sample show the value of 7.51 and the quality standard value based on Peraturan Menteri Lingkungan Hidup RI Nomor 5 tahun 2014 is 6 to 9 , therefore the parameters still meet the existing quality standards.

\subsection{2. $\operatorname{Iron}(\mathrm{Fe})$}

Iron test follows the IK NO.15.34/IK/LL/2018 method, where the sample has an iron content 0.018 $\mathrm{mg} / \mathrm{L}$ with the sample color which initially turbid and then shows a slightly pink color due to the iron content in the sample. High levels of iron can be harmful to living things if they form in ionic bonds and release to the environment, therefore Peraturan Menteri Lingkungan Hidup RI Nomor 5 tahun 2014 set the maximum limit of iron in hospital wastewater of $5 \mathrm{mg} / \mathrm{L}$, this value is meet the quality standards from the government.

\subsubsection{Manganese (Mn)}

Manganese is a heavy metal that must be considered the level in wastewater. In nature, manganese is found in the soil, which when it comes into contact with the waste stream the manganese content in the waste can increase. Too much manganese in wastewater can cause sedimentation and discoloration in the water [4]

Analysis of manganese content was carried out using the IK NO. 15. 32/IK/ LL/ 2018 method, where the sample measured the manganese content 0.013 $\mathrm{mg} / \mathrm{L}$ and showed sedimentation after add on reagent. Regulation from Peraturan Menteri Lingkungan Hidup RI Nomor 5 tahun 2014 stipulates that the quality standard for manganese levels does not exceed $2 \mathrm{mg} / \mathrm{L}$, so that the manganese content in the sample meets existing quality standards.

\subsubsection{Copper $(\mathrm{Cu})$}

Copper levels in the sample were measured using the IK NO.15.27/ IK/LL/2018 method, which is based on Peraturan Menteri Lingkungan Hidup RI Nomor 5 tahun 2014 states that the quality standard of copper is not more than $2 \mathrm{mg} / \mathrm{L}$. The sample met the standard because the measured copper content was $0.020 \mathrm{mg} / \mathrm{L}$ and did not exceed the quality standard, the sample did not show a change in color after add on reagent. Copper itself is a heavy metal which if the concentration is high can be toxic to living things, therefore it is necessary to pay attention to its presence in wastewater.

\subsubsection{Nitrite $\left(\mathrm{NO}_{2}{ }^{-}\right)$}

The level of nitrite needs to be measured in the wastewater, because it is very easy to react and is toxic to animals and humans. Based on Peraturan Menteri Lingkungan Hidup RI Nomor 5 tahun 2014 states that the nitrite level should not exceed $1 \mathrm{mg} / \mathrm{L}$, while in the sample the measured nitrite content is $0.008 \mathrm{mg} / \mathrm{L}$ without showing a change in color after add on reagent so that it still meets the quality standard.

\subsubsection{Sulfide $\left(S^{2-}\right)$}

Sulfide has corrosive properties and can be harmful to living things, therefore Peraturan Menteri Lingkungan Hidup RI Nomor 5 tahun 2014 provides a rule for sulfide levels in hospital wastewater which is not more than $0.05 \mathrm{mg} / \mathrm{L}$. The waste sample shows a value that meets quality standards using the IK NO.15.31/IK/LL/ 2018 method and had a value 0.005 
$\mathrm{mg} / \mathrm{L}$ and there is no color change after add on reagen.

According to [5], hardness in water is divided into two which is temporary hardness and permanent hardness. Hardness is caused by sulfate (SO42-) which is the result of sulfide ion bonds, so the sulfide level in the waste must be considered so that not cause hardness in water.

\subsection{7. $B O D$}

Measurement of Biochemical Oxgen Demand (BOD) was carried out using the SNI 6989.72-2009 method, where measured from sample shows BOD value 25. Based on Peraturan Menteri Lingkungan Hidup dan Kehutanan RI Nomor P.68/MenlhkSetjen/2016, the BOD quality standard value is not exceeding $30 \mathrm{mg} / \mathrm{L}$, so that the sample still meets the quality standard. The calculation formulas used in the BOD analysis are:

$$
\begin{aligned}
& \mathrm{BOD}_{5}=\frac{\left(\mathrm{A}_{1}-A_{2}\right)-\left(\frac{\left(\mathrm{B}_{1}-\mathrm{B}_{2}\right)}{V_{B}}\right) \mathrm{V}_{\mathrm{c}}}{\mathrm{P}} \\
= & \frac{(5,10-2,87)-\left(\frac{5,83-5,29}{30}\right) 30}{\frac{20}{300}} \\
= & (2,23-0,54) \frac{300}{20} \\
= & 25,35=25 \mathrm{mg} / \mathrm{l}
\end{aligned}
$$

\section{Notes:}

BOD5 = BOD value from sample $(\mathrm{mg} / \mathrm{L})$

A1 = Dissolved oxygen content from sample before incubaton (0 day) $(\mathrm{mg} / \mathrm{L})$

A2 = Dissolved oxygen content from sample after incubaton (5 day) ( $\mathrm{mg} / \mathrm{L}$ )

B1 = Dissolved oxygen content from control before incubaton ( 0 day) $(\mathrm{mg} / \mathrm{L})$

B2 = Dissolved oxygen content from control after incubaton (5 day) ( $\mathrm{mg} / \mathrm{L})$

$\mathrm{VB}=$ Microbe suspension volume $(\mathrm{mL})$ in $\mathrm{DO}$ bottle (control)

$\mathrm{Vc}=$ Microbe suspension volume $(\mathrm{mL})$ in $\mathrm{DO}$ bottle (sample)

$\mathrm{P} \quad=$ Volume ration sample (V1) divided total volume (V2).

BOD itself is the level of oxygen required by microorganisms to break down organic substances in wastewater, the higher BOD value will show the higher content of organic matter. The high level of organic matter can affect the aquatic ecosystem because organic substances act as nutrients that can nourish the growth of aquatic organisms.

\subsection{8. $C O D$}

According to [6], the value of COD (Chemical Oxygen Demand) is the amount of oxygen required to oxidize the organic substances in the sample. With this measurement it can be seen the value of contamination from organic substances in wastewater.

The number of COD based on Peraturan Menteri Lingkungan Hidup dan Kehutanan RI Nomor P.68/Menlhk-Setjen/2016 should not exceed 100 $\mathrm{mg} / \mathrm{L}$. The samples tested using SNI 6989.2-2009 method showed a value of $55 \mathrm{mg} / \mathrm{L}$ where the sample still met quality standards.

\subsubsection{Oils and Fats}

Based on Peraturan Menteri Lingkungan Hidup dan Kehutanan RI Nomor P.68/Menlhk-Setjen/2016 set the maximum limit for oils and fats content in wastewater is $5 \mathrm{mg} / \mathrm{L}$. While the sample shows a value of $0.017 \mathrm{mg} / \mathrm{L}$, so that it still meets the quality standard.

Oils is a liquid form of fats, both are insoluble in water because they are composed of carbon and hydrogen, besides those oils and fats are relatively stable so they are difficult to be broken down by microorganisms [7]. Therefore, it is necessary to pay attention to the levels of oils and fats in the waste before release to the environment, where the analysis of oils and fats levels is carried out by measuring the levels of oils and fats in a sample with the formula:

$$
\begin{aligned}
\text { oF }(\boldsymbol{m g} / \boldsymbol{l}) & =\frac{\text { Final weight }(\mathbf{m g})-\text { Initial weight }(\mathbf{m g})}{\text { Sample volume }(\boldsymbol{l})} \\
& =\frac{158,2525-158,2351}{1} \\
& =0,0174=\mathbf{0}, \mathbf{0 1 7}
\end{aligned}
$$

\subsubsection{MBAS (Methylene Blue Active Surfactant)}

Analysis of Methylene Blue Active Surfactant used to determinated surfactant using methylene blue. Surfactant itself is an organic material found in detergents, this material is alkaline and can be dangerous if had a large amount in the water. According to Peraturan Menteri Lingkungan Hidup RI Nomor 5 tahun 2014, the surfactant level in wastewater must not exceed $10 \mathrm{mg} / \mathrm{L}$, while the 
surfactant content in the sample shows value of 0.306 $\mathrm{mg} / \mathrm{L}$ which still meets the quality standard.

\subsubsection{Ammonia $\left(\mathrm{NH}_{3}-\mathrm{N}\right)$}

Based on Peraturan Menteri Lingkungan Hidup RI Nomor 5 tahun 2014, the level of free ammonia in wastewater is not more than $1 \mathrm{mg} / \mathrm{L}$. In the sample, ammonia levels were measured using the SNI 6989.30-2005 method and had a value $0.860 \mathrm{mg} / \mathrm{L}$, this indicates that ammonia levels in hospital waste still meet quality standards.

\subsection{Microbiology Parameters}

\subsubsection{Total Coliform}

Based on Peraturan Menteri Lingkungan Hidup dan Kehutanan RI Nomor P.68/Menlhk-Setjen/2016. The total coliform quality standard value in hospital wastewater does not exceed $3000 \mathrm{MPN} / 100 \mathrm{ml}$. The test using MPN (Most Probable Number) method, it was found that the total coliform value in hospital wastewater was $2940 \mathrm{MPN} / \mathrm{ml}$, this shows that sample still meets the quality standard. The value of the MPN test was found after the number of positive tubes from the confirmed test was adjusted to the MPN measurement table, after finding the MPN index the value was multiplied by the dilution.

Total Coliform $(M P N / 100 m l)=$ Indeks $M P N \times 10$

$=294 \times 10$

$=2940$

Coliform testing is useful for knowing the presence of coliform bacteria contamination in water, where coliform bacteria are digestive bacteria which are divided into two types, namely coliform and fecal coliform. Fecal coliform bacteria is an indicator of water contaminated with feces from humans and animals, therefore testing needs to be done to prevent pathogenic microbes in the water [8].

\section{CONCLUSION}

Based on the results of the analysis of hospital wastewater in Bengkulu City, it is known that the hospital wastewater treatment system works well, where the parameters tested (temperature, TSS, $\mathrm{pH}$, $\mathrm{Fe}, \mathrm{Mn}, \mathrm{Cu}, \mathrm{NO}^{2-}, \mathrm{S}^{2-}, \mathrm{BOD}, \mathrm{COD}$, oils and fats, MBAS, $\mathrm{NH}_{3}-\mathrm{N}$, and total coliform) showed values that meet quality standards based on Peraturan Menteri Lingkungan Hidup RI Nomor 5 tahun 2014 and Peraturan Menteri Lingkungan Hidup dan Kehutanan RI Nomor P.68/Menlhk-Setjen/2016.

\section{REFERENCES}

[1] P. Nasoetion, D.A. Wulandari, M. Saputra, Maulizar, R.I. Ergantara, Evaluasi dan redesign instalasi pengolahan air limbah (IPAL) RS. Pertamina Bintang Amin Bandar Lampung, Jurnal Rekayasa, Teknologi, dan Sains 1(2) (2017). [In Bahasa Indonesia]

[2] Mallongi, B.A. Rahmat, Studi Karakteristik dan Kualitas BOD dan COD Limbah Cair Rumah Sakit Umum Daerah Lanto DG. Pasewang Kabupaten Jeneponto, Jurnal Nasional Ilmu Kesehatan 1(1) 2018 1-19. [In Bahasa Indonesia]

[3] A. Gafur, Efisiensi instalasi pengolahan air limbah terhadap kualitas limbah cair Rumah Sakit Haji Makassar tahun 2014, HIGIENE: Jurnal Kesehatan Lingkungan 1(1) (2015) 1-8. [In Bahasa Indonesia]

[4] R. Yunus, I.A. Rahayu, D. Ariyani, Analisis kandungan mangan (Mn) pada air sumur di sekitar kawasan pertambangan batubara di Kecamatan Simpang Empat Kabupaten Banjar, Sains dan Terapan Kimia 14(1) (2020) 43-54. [In Bahasa Indonesia]

[5] Asmaningrum, P. Henie Penentuan Kadar Besi $(\mathrm{Fe})$ dan Kesadahan pada Air Minum Isi Ulang di Distrik Merauke. Magistra. 3(2). 2016. [In Bahasa Indonesia]

[6] W. Wardhana, Dampak Pencemaran Lingkungan, ANDI, Yogyakarta, 2004. [In Bahasa Indonesia]

[7] F. Mubin, B. Alex, F. Halim, Perencanaan sistem pengolahan air limbah domestik di Kelurahan Istiqlal Kota Manado, Jurnal Sipil Statik. 4(3) (2016) 211-223. [In Bahasa Indonesia]

[8] M. Ikhtiar, Analisis kualitas lingkungan, CV. Social Politic Genius, Makassar, 2017. [In Bahasa Indonesia] 